\title{
NOTES ON BIRDS AND OTHER ANIMALS IN THE SLAVE RIVER - LITTLE BUFFALO RIVER AREA, N.W.T.
}

\author{
by Robert E. Stewart, Jamestown, North Dakota
}

In 1955, from May 20 to June 20 inclusive, a biological reconnaissance was made of the Slave River-Little Buffalo River area, located in centralsouthern District of Mackenzie, Northwest Territories, Canada, during an attempt to reach the nesting grounds of the Whooping Crane. The writer was accompanied on this expedition by Robert P. Allen of the National Audubon Society and Raymond Stewart of the Canadian Wildlife Service.

We travelled to and from the various areas that were surveyed by automobile, airplane, helicopter, motor canoe, canoe and paddle, and on foot. The localities visited are listed in chronological order in the following itinerary :

May 20-22-Vicinity of Fort Smith, including a visit to the Salt River area, a few miles to the north.

May 23-Travelled downstream by canoe on Slave River, from Fort Smith to Grand Detour Portage.

May 24-25-On foot, along Grand Detour Portage, between Slave and Little Buffalo Rivers.

May 26-Travelled upstream by canoe on Little Buffalo River from Grand Detour Portage to mouth of Sass River.

May 27-Travelled downstream by canoe on Little Buffalo River from mouth of Sass River to Great Slave Lake.

May 28-30-Shore of Great Slave Lake, at mouth of Little Buffalo River. May 31-June 4-Vicinity of Fort Smith, including a visit to Salt River on June 1, and one day at Tsu Lake on June 2.

June 5-16-Vicinity of base camp, located along Sass River, between two and four miles above its junction with Little Buffalo River.

June 17-18-Travelled downstream on foot along Sass River and upper Little Buffalo River to Grand Detour Portage.

June 19-20--On foot, along Grand Detour Portage, between Little Buffalo and Slave Rivers.

The annotated lists of birds and other animals included in this report are based on field notes made by the writer, unless otherwise indicated. In addition to these observations, detailed population studies of breeding birds were made during June 13-16 on two 15-acre tracts of white spruce along the Sass River, a tributary of the Little Buffalo River that is located within the Wood Buffalo National Park. These population studies were published in Audubon Field Notes, 9 (6), 1955. A few of the bird records listed in the report were sent to Dr. Alexander Wetmore, and were useful in helping to delineate the northern limits of breeding ranges of birds as shown in the 1957 A.O.U. Check-list. One species, the Mourning Warbler, not listed in the report, probably also breeds in the area covered. On two or three occasions I thought I heard distant songs of this species along the Little Buffalo River, but was never quite positive enough to put them down as definite records. Although somewhat generalized, these notes may be of interest since they cover an unusually interesting faunistic area that is difficult of access and even more difficult to work in due to a nearly overwhelming scourge of mosquitoes.

\section{Accounts of Birds}

Horned GREBe Podiceps auritus. Common in open cattail (Typha latifolia) sloughs throughout the Grand Detour Portage and Little Buffalo River areas. Courtship display noted on May 24. 


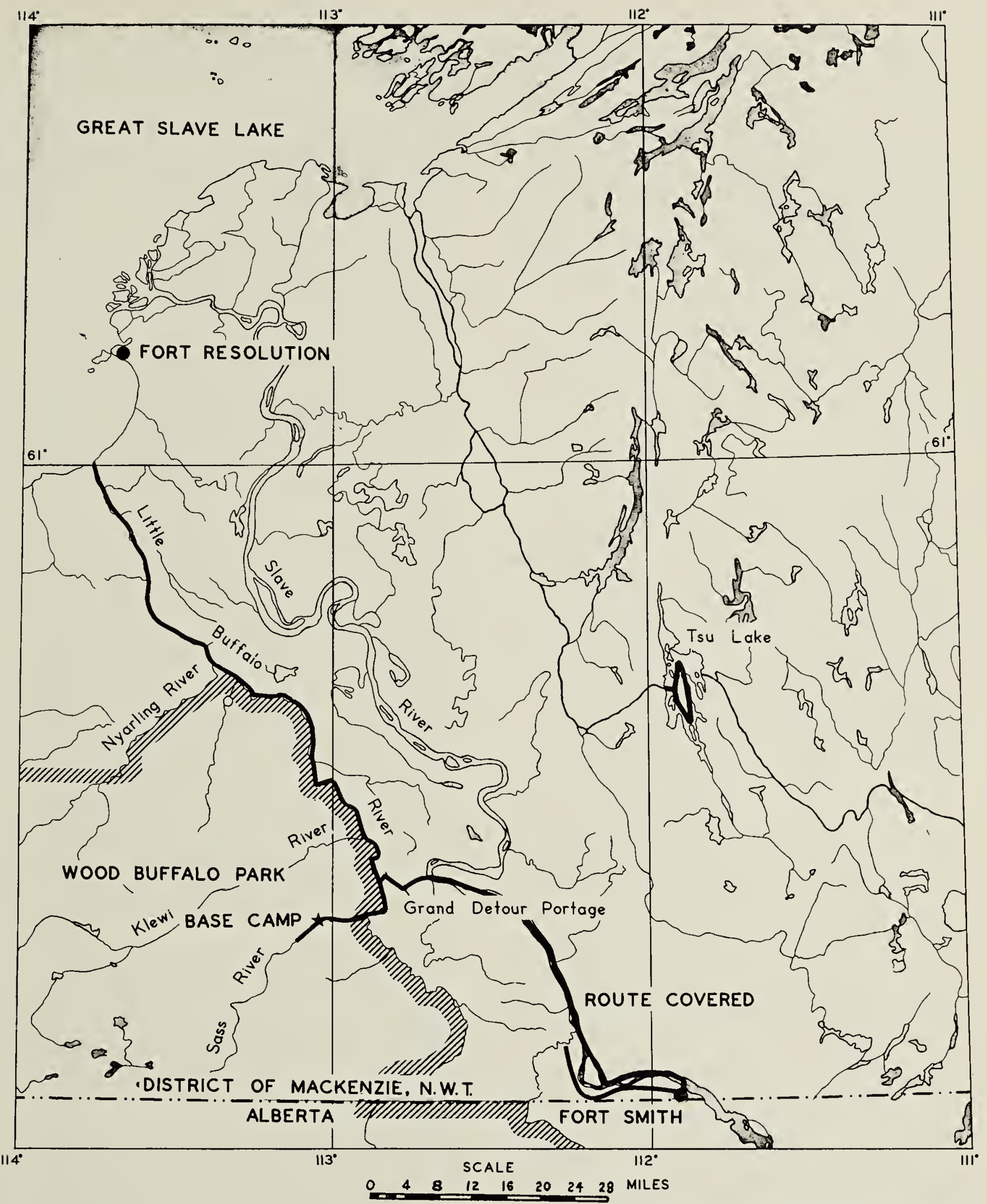

Drawn by Dr. Lewis M. Cowardin Slave River-Little Buffalo River area; heavy black lines show routes covered.

White Pelican Pelecanus erythrorhynchos. Thirty to 40 seen at Slave River rapids near Fort Smith on May 31.

A MERICAN BITTERN Botaurus lentiginosus. Heard calling in cattail sloughs at several locations in the Grand Detour Portage - Little Buffalo River areas.
Whistling SWAN Olor columbianus. A migrating flock of 15 was observed overhead on May 25.

CANADA Goose Branta canadensis. A few scattered pairs were noted in open sloughs along the Little Buffalo River. A small migrating flock was observed overhead on June 6 .

SNow Goose Chen hyperborea. A 
migrating flock, containing about 25 individuals, was observed overhead on May 23.

Mallard Anas platyrhynchos. Fairly common as scattered pairs in open sloughs in the Grand Detour Portage area, and along the Little Buffalo and Sass Rivers. A total of 45 individuals was flushed along an 80-mile stretch of Little Buffalo River on May 27.

BlACK DUCK Anas rubripes. A single bird was observed with a flock of Mallards on Great Slave Lake, near the mouth of Little Buffalo River, on May 29.

Pintail Anas acuta. A few scattered pairs were observed in open sloughs in the Grand Detour Portage area and along the Little Buffalo and Sass Rivers. A nest containing eight nearly fresh eggs was found under a spruce log along the Little Buffalo River on May 26, and another nest with eggs was found at Slave River rapids near Fort Smith on May 31.

Green-Winged Teal Anas carolinensis. Common in the open sloughs in the Grand Detour Portage area and along the Little Buffalo and Sass Rivers. A total of 62 individuals was flushed along an 80-mile stretch of Little Buffalo River on May 27.

SHoveler Spatula clypeata. A few scattered pairs were observed in open sloughs in the Grand Detour Portage area and along the Little Buffalo and Sass Rivers.

AMERICAN WIDGEON Mareca americana. Probably the most common breeding species of dabbling duck, occurring in open sloughs in the Grand Detour Portage area and along the Little Buffalo and Sass Rivers. A total of 69 individuals was flushed along an 80-mile stretch of the Little Buffalo River on May 27.

RING-NECKED DUCK Aythya collaris. Apparently uncommon. One pair was seen along Long Slough along the Grand Detour Portage on May 25, and another pair on the Little Buffalo River on May 27.

Canvasback Aythya valisineria. A few scattered pairs were noted in open sloughs along the Grand Detour Portage and near the Little Buffalo River.

Lesser Scaup Aythya affinis. A few scattered pairs recorded in open sloughs along the Grand Detour Portage and on the Little Buffalo River.

Common Goldeneye Bucephala clangula. Common along the Little Buffalo River, and a few pairs were seen on the Sass River. This is the most numerous specie's of diving duck in the region. On May 27, a total of 199 individuals was flushed along an 80-mile stretch of Little Buffalo River. A hen with 10 tiny, newly-hatched young was observed on the Sass River on June 12.

BUFFLEHEAD Bucephala albeola. Fairly common in open sloughs along the Grand Detour Portage, and on the Little Buffalo River. On May 27, a total of 18 individuals was flushed along an 80-mile stretch of the Little Buffalo River. On this date, a male Bufflehead wa's observed fighting and chasing a female Lesser Scaup.

RudDY Duck Oxyura jamaicensis. Apparently uncommon. On June 20, Robert P. Allen observed a pair exhibiting courtship behaviour on Long Slough near the west end of Grand Detour Portage.

COMMON Merganser Mergus merganser. Recorded on lakes in Precambrian shield country, east of Slave River, but not observed in the Grand Detour Portage - Little Buffalo River area.

RED-BREASTED MerganseR Mergus serrator. Recorded on lakes in Precambrian shield country, east of Slave River, but not observed in the Grand Detour Portage - Little Buffalo River area.

Goshawk Accipiter gentilis. Apparently uncommon. One was seen along the Little Buffalo River on May 27.

SharP-SHINNED HaWk Accipiter striatus. Apparently uncommon. One was seen near the mouth of the Sass River on May 25.

RED-TAILED HAWK Buteo jamaicensis. One recorded along Grand Detour 
Portage on June 20.

HARLAN'S HAWK Buteo harlani or melanistic Red-tailed Hawk. Three recorded along the Little Buffalo River, between mouth of Sass River and Great Slave Lake on May 26 and May 27.

Golden EAgLe Aquila chrysaetos. An eagle, almost certainly this species, was observed being chased by Ravens on June 7, along the Sass River.

BALD EAGLE Haliaeetus leucocephalus. Three adults recorded along Little Buffalo River, between mouth of the Sass River and Great Slave Lake on May 26 and May 27.

Marsh Hawk Circus cyaneus. Two were observed in open prairie, near the Little Buffalo River on May 25 and May 29.

Peregrine Falcon Falco peregrinus. A pair was observed near the mouth of the Sass River on May 25 and May 27. These birds were about two miles from a large limestone escarpment.

SPARROW HAWK Falco sparverius. Scattered birds were observed in open "brule" and prairie edge situations in the Grand Detour Portage area and along the Little Buffalo and Sass Rivers.

SPRUCE Grouse Canachites canadensis. Common in white spruce (Picea glauca) forests, particularly in stands located in alluvial bottomlands - apparently much less common in spruce forests of the upland. In a 15-acre tract of bottomland spruce along the Sass River, from two to four males were flushed repeatedly.

Ruffed Grouse Bonasa umbellus. Fairly common in extensive stands of quaking aspen (Populus tremuloides) along the Grand Detour Portage.

Willow Ptarmigan Lagopus lagopus. Remains, including feathers and wing fragments of several were found along the shore of Great Slave Lake, near the mouth of the Little Buffalo River - indicating that this species had been common during the previous winter.

Sharp-TaIled Grouse Pedioecetes phasianellus. Fairly common in brushy prairie edge situations along the Grand Detour Portage.

Whooping CRANe Grus americana. Heard calling at night near base camp on Sass River on June 6 and 7. During an airplane flight over this general area, one was observed on May 22.

SANDhill Crane Grus canadensis. Fairly common in the vicinity of shallow, prairie potholes along the Grand Detour Portage. Noticeably more numerous from May 24 - 27, than during the period, June 18-20. Apparently, this was due to the fact that many of the prairie potholes had dried up during the intervening period.

SorA Porzana carolina. Frequently heard calling in cattail sloughs in the Grand Detour Portage area and near the Little Buffalo and Sass Rivers.

YELLOW RAIL Coturnicops noveboracensis. Call notes, almost certainly of this species, were heard in a sedgemeadow near the mouth of the Sass River on May 26.

Semipalmated Plover Charadrius semipalmatus. Several individuals, possibly migrants, were observed at the mouth of the Little Buffalo River on May 29.

Common SNIPE Capella gallinago. Fairly common in marsh and sedgemeadow situations in the Grand Detour Portage area and along the Little Buffalo and Sass Rivers. Territorial or courtship flights were noted at all camping locations.

SPOTTED SANDPIPER Actitis macularia. Scattered breeding pairs were recorded along the Little Buffalo and Sass Rivers, and in marshy sloughs along the Grand Detour Portage. On May 27, apparently during the peak of migration, a total of 210 individuals was seen along an 80-mile stretch of the Little Buffalo River.

Solitary SANDPIPER Tringa solitaria. Rather uncommon as scattered breeding pairs along the Little Buffalo River and in nearby sloughs.

Lesser Yellowlegs Totanus flav- 
ipes. Breeding pairs were found to be common in wet prairie-edge situations along the Grand Detour Portage and near the Little Buffalo River.

Pectoral SANDPIPER Erolia melanotos. A flock of 18 migrants was observed along the Little Buffalo River on May 27.

HERRING GULL Larus argentatus. Fairly common along Great Slave Lake, on wider portions of the Little Buffalo River, and on the Slave River. Also occurred sparingly in the vicinity of the larger potholes along the Grand Detour Portage. Several nests with eggs were found on rocks in Slave River rapids at Fort Smith on May 31.

MEW GULL Larus canus. Fairly common along Great Slave Lake, on the Slave River, and on wider portions of the Little Buffalo River. Also occurred sparingly in the vicinity of the larger potholes in the Grand Detour Portage area. On May 31, several nests with eggs were found on wood debris lying on rocks in the Slave River rapids near Fort Smith. Another nest with eggs, found at Tsu Lake on June 2, is probably near the northeastern margin of the breeding range.

BoNAPARTE'S GULL Larus philadelphia. Several were recorded at the mouth of the Little Buffalo River during the period, May 28-30.

ARCTIC TERN Sterna paradisaea. Several observed in the mouth of the Little Buffalo River and in adjacent portions of Great Slave Lake during the period, May 28-30.

Great Horned OWL Bubo virginianus. Heard calling at Salt River, north of Fort Smith, on June 1.

Great Gray OWL Strix nebulosa. Four, including one pair and two singles, were observed along an 80mile stretch of the Little Buffalo River, from the mouth of Sass River to Great Slave Lake, on May 27. A series of soft "who's" heard along the Sass River during the period, June $5-16$, probably also were of this species.
SHORT-EARED OWL Asio flammeus. At least one was observed repeatedly, near the mouth of the Little Buffalo River during the period, May 28-30.

Common Nighthawk Chordeiles minor. Fairly common in all locations visited. First observed along shore of Great Slave Lake on May 28 (?arrival date).

BeLted Kingfisher Megaceryle alcyon. A few scattered pairs were recorded along the Sass and Little Buffalo Rivers, and nesting tunnels were observed in both areas. On May 27, a total of 12 individuals was seen along an 80-mile stretch of the Little Buffalo River.

YELLOW-SHAFTED FLICKER Colaptes auratus. Fairly common throughout. Especially characteristic of brushy "brule" country and prairie edge situation. On May 26, a pair was observed working on a nest hole in a dead balsam poplar.

Pileated WoodPecker Dryocopus pileatus. Several were recorded in the heavily wooded alluvial bottomlands along the Little Buffalo and Sass Rivers, above the Grand Detour Portage. This area is probably near the extreme northern limit of the breeding range.

YeLlOW-BELlied SAPSUCKer Sphyrapicus varius. Common throughout. Especially characteristic of aspen stands.

HAIRY WOODPECKER Dendrocopos villosus. Fairly common in the more densely forested tracts throughout the Grand Detour Portage, Little Buffalo River, and Sass River areas. One observed entering nest hole five feet above the ground in a live quaking aspen on May 27.

Downy WoODPECKer Dendrocopos pubescens. Apparently uncommon or rare. One was observed near the mouth of the Sass River on June 18. This locality probably is near the northern limit of the breeding range.

BLACK-BACKED THREE-TOED WOODPECKER Picoides arcticus. Apparently uncommon or rare. One was observed in a dense white spruce tract along 
the Sass River on June 17.

NORTHERN THREE-TOED W OODPECKER Picoides tridactylus. Probably uncommon. A pair was observed in upland white spruce forest, about one mile from the Sass River on June 16, and a single was seen near the mouth of the Sass River on June 17.

EASTERN KINGBIRD Tyrannus tyrannus. Scattered pairs throughout the Grand Detour Portage, Little Buffalo River and Sass River areas. Especially characteristic of brushy "brule" habitat.

Eastern Phoebe Sayornis phoebe. Two or three pairs were noted along the Little Buffalo River. An occupied nest was seen in the entrance of an old Belted Kingfisher burrow on May 27.

YELLOW-BELLIED FLYCATCHER $E m$ pidonax flaviventris. Apparently uncommon or rare. One was observed in a dense tract of bottomland white spruce along the Sass River on June 13.

Traill's Flycatcher Empidonax traillii. Fairy common in wet brushy tracts overgrown with willows and other shrubs, in the Grand Detour Portage, Little Buffalo River and Sass River areas. First noted on June 10 (? arrival date).

LEAST FLYCATCHER Empidonax minimus. Rather common throughout the Grand Detour Portage, Little Buffalo River and Sass River areas, usually occurring in stands of quaking aspen.

Western Wood Pewee Contopus sordidulus. A total of three was recorded in quaking aspen stands near the Sass River, the first on June 13 (?arrival date).

OLIVE-SIDED FLYCATCHER Nuttalornis borealis. Fairly common throughout the Grand Detour Portage, Little Buffalo River and Sass River areas, particularly in "brule" habitats. First observed on May 27 (? arrival date).

HORNED LARK Eremophila alpestris. A pair was observed on a small prairie near the mouth of the Little Buffalo River on May 29. Large flocks of migrants were noted at Fort Smith during the period, May 20-23.

TREE SWALlow Iridoprocne bicolor. Fairly common throughout the Grand Detour Portage, Little Buffalo River and Sass River areas. Characteristic of forest edge situations along ponds, sloughs, and streams.

GRAY JAY Perisoreus canadensis. Common in forested tracts throughout. This is probably the most conspicuous bird in the area. Many birds in juvenal plumage were seen, the first on May 30.

Common Raven Corvus corax. Occasional singles or pairs were noted in all areas visited.

COMMON CRow Corvus brachyrhynchos. Two singles and one pair were recorded along the Little Buffalo River. One was observed near the mouth of the river, chasing a Raven (? breeding territorial behaviour).

BLACK-CAPPED CHICKA DE Parus atricapillus. Recorded at three locations along the Little Buffalo River.

Boreal Chickadee Parus hudsonicus. Fairly common in white spruce forests at Fort Smith and in the Grand Detour Portage, Little Buffalo River and Sass River areas.

Red-BREASTED N U T H A T H Sitta canadensis. At least one pair was observed on three occasions in a tract of white spruce along the Sass River, about two miles above its mouth, during June 5-16. This locality is probably near the northern limit of the breeding range.

RoBIN Turdus migratorius. Fairly common in edge habitats throughout. A nest with eggs (embryo about $1 / 3$ developed) was situated about four feet above the ground in a willow on May 26. Young were flushed out of a nest on June 20.

Hermit Thrush Hylocichla guttata. Fairly common in quaking aspen stands and edge situations throughout the Grand Detour Portage, Little Buffalo River and Sass River areas.

SWAINSON's THRUSH Hylocichla ustulata. Common in white spruce forests in all areas visited. Population 
studies along the Sass River during June 13-16, indicated the density of territorial males to be about 33 per 100 acres in bottomland spruce and about 13 per 100 acres in upland spruce.

Mountain Bluebird Sialia currucoides. On June 18, Robert P. Allen closely observed a pair along the Little Buffalo River, near the mouth of the Sass River.

RUBY - CROWNED KINGLET Regulus calendula. Fairly common in white spruce forests in all areas visited. Population studies along the Sass River during June 13-16, indicated the density of territorial males to be about 10 per 100 acres in bottomland spruce and about 13 per 100 acres in upland spruce.

WATER PIPIT Anthus spinoletta. Several migrants were recorded in a large prairie along the Grand Detour Portage on May 23.

Waxwing Bombycilla. Distant small flocks were observed at two locations along the Little Buffalo River on June 18 and June 19.

STARLING Sturnus vulgaris. Several were observed in prairie edge situations along the Little Buffalo River.

SOLITARY VIREO Vireo solitarius. Fairly common in bottomland white spruce forests along the Little Buffalo and Sass Rivers. Population studies along the Sass River during June 13-14, indicated the density of territorial males to be about 13 per 100 acres. These localities are probably near the northern limit of the breeding range.

RED-EYED VIREO Vireo olivaceus. Fairly common in quaking aspen stands in the Grand Detour Portage, Little Buffalo River and Sass River areas.

WARBLing Vireo Vireo gilvus. Apparently rare. A singing male was observed in a quaking aspen stand along the Grand Detour Portage on June 20.

BLACK-AND-WHITE WARBLER Mniotilta varia. Fairly common in quaking aspen stands in the Grand Detour
Portage, Little Buffalo River and Sass River areas.

TEN NESSEE WARBLER Vermivora peregrina. Common and widely distributed throughout the Grand Detour Portage, Little Buffalo River and Sass River areas. Occurs in forest and forest edge situations, including both spruce and aspen types. Population studies in bottomland white spruce along the Sass River during June 13-14, indicated the density of territorial males to be about 33 per 100 acres.

ORANGE-CROWNED WARBLER Vermivora celata. A pair exhibiting breeding behaviour was seen in a brushy thicket along the mouth of the Little Buffalo River on May 28.

Yellow WaRbler Dendroica petechia. Fairly common, locally, in the Grand Detour Portage, Little Buffalo River and Sass River areas. Occurs in wet brushy thickets.

Magnolia WARBLER Dendroica magnolia. A few were recorded in dense stands of young (brush stage) white spruce near the Sass River. First observed on June 5 (? arrival date).

CAPE May Warbler Dendroica tigrina. Uncommon. A few scattered territorial males were observed in dense bottomland white spruce forest along the Sass River. First noted on June 5 (? arrival date).

MYRTLE WARBLeR Dendroica coronata. Common in white spruce forests in all areas visited. Population studies along the Sass River during June 13-16 indicated the density of territorial males to be about 40 per 100 acres in bottomland spruce, and about 33 per 100 acres in upland spruce.

BAy-BREASTED WARBLER Dendroica castanea. Uncommon or rare. Single singing males recorded at three locations in dense bottomland white spruce along the Sass River. First noted on June 6 (? arrival date).

B LACKPOLL WARBLER Dendroica striata. A few singing males (possibly late migrants) were observed in brushy forest-edge situations as late as June 18. 


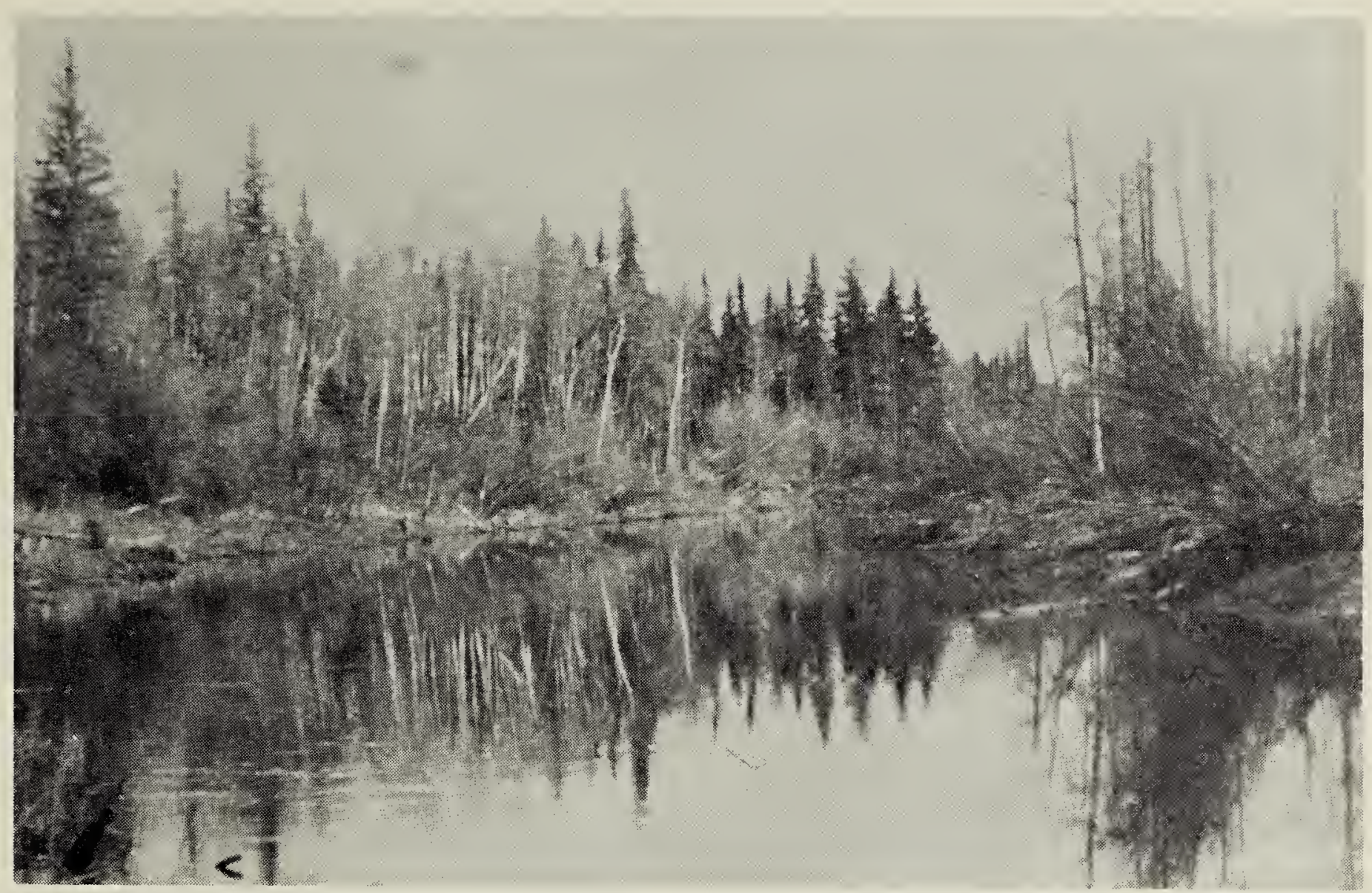

Photo by R. E. Stewart

Little Buffalo River near Grand Detour Portage, May 27, 1955

PALM WARBLer Dendroica palmarum. Fairly common locally along the Little Buffalo and Sass Rivers, occurring in brushy bog situations. These localities are probably near the northern margin of the breeding range.

NORTHERN WATERTHRUSH Seiums noveboracensis. Fairly common in wet forested or brushy tracts along the Grand Detour Portage, Little Buffalo River and Sa'ss River.

YeLLOWTHROAT Geothlypis trichas. Uncommon and local. A few scattered singing males were recorded in wet, brushy habitats along the Grand Detour Portage, Little Buffalo River and Sass River. These localities are probably near the northern margin of the breeding range.

WILSON'S WARBLER Wilsonia pusilla. Uncommon. A few scattered singing males were recorded in moist brushy thickets along the Little Buffalo and Sass Rivers.

American Reds a R T Setophaga ruticilla. Uncommon and local. A few singing males were observed in willow and balsam poplar (Populus balsamifera) growth along the Little Buffalo River.

Red - Winged BlackBIRd Agelaius phoeniceus. Fairly common in cattail sloughs along the Grand Detour Portage, and along the Little Buffalo and Sass Rivers.

RUsty BlackBIRD Euphagus carolinus. Uncommon and local. A few scattered pairs were recorded in wet brushy tracts along the Grand Detour Portage, and along the Little Buffalo and Sass Rivers.

Common GrackLe Quiscalus quiscula. Uncommon. A few pairs were observed along the shore of the Little Buffalo River, from the mouth of the Sass River to Great Slave Lake. This locality is probably near the northern margin of the breeding range.

BROWN-HEADED CowBIRD Molothrus ater. One observed along Grand Detour Portage on May 25.

Western TANager Piranga ludoviciana. Fairly common in white spruce forests along the Little Buffalo and Sass Rivers and near the Salt River. 
First noted at Salt River on May 22 (? arrival date). Population studies along the Sass River during June 1316 indicated the density of territorial males to be about 10 per 100 acres in both bottomland and upland spruce.

\section{Rose-Breasted Grosbeak Phoucti-} cus ludovicianus. Several singing males were observed in wooded areas along the Little Buffalo River, chiefly along the stretch between the mouth of the Sass River and Grand Detour Portage. This locality probably represents the extreme northern limit of the breeding range.

PURPle Finch Carpodacus purpureus. Several were noted in spruce or mixed forest along the Little Buffalo River. This locality probably represents the extreme northern limit of the breeding range.

Pine Siskin Spinus pinus. Uncommon. A few were recorded in white spruce forests along the Little Buffalo and Sass Rivers.

White-Winged CRossbill Loxia leucoptera. Uncommon. A flock containing about 20 individuals was observed on several occasions in dense white spruce forest along the Sass River (one bird collected).

Savannah SPARRow Passerculus sandwichensis. Common in open prairies along the Grand Detour Portage and along the Little Buffalo River and Sass River.

Le Conte's SPARRow Passerherbulus caudacutus. Fairly common in wet prairies or sedge-meadows along the Grand Detour Portage and along the Little Buffalo River. These localities are probably near the extreme northern limit of the breeding range.

Vesper Sparrow Pooecetes gramineus. Fairly common in prairie-edge situations along the Grand Detour Portage. On June 18, a total of five territorial males or pairs were observed, during a six-mile walk along a large prairie in this area. This locality is probably near the northern margin of the breeding range.

SlATE-COLORED JUNCO Junco hyemalis. Common in forest and forest-edge habitats in all areas visited. A nest containing five nearly full-grown young was found on June 14 along the Sass River. Population studies along the Sass River during June 13-16, indicated the density of territorial males to be about 27 per 100 acres in bottomland white spruce forest, and about 13 per 100 acres in upland white spruce forest.

ChIPPING Sparrow Spizella passerina. Common in forest and forestedge habitats in all areas visited. On June 12, a nest containing four eggs and situated in a shrub willow one foot above the ground was found along the Sass River. Population studies along the Sass River during June 13-16, indicated the density of territorial males to be about 27 per 100 acres in bottomland white spruce forest and about 30 per 100 acres in upland white spruce forest.

Clay-COlored SPARROW Spizella pallida. Fairly common locally in dry brushy habitats along the Salt River, Grand Detour Portage, Little Buffalo River and Sass River. These localities are probably near the northern margin of the breeding range.

White-CROWNED SPARRoW Zonotrichia leucophrys. Fairly common locally in all areas visited. Especially characteristic of upland well-drained areas with an open growth of scattered shrubs. Breeding pairs also were found to be fairly common within the town of Fort Smith.

White-Throated Sparrow Zonotrichia albicollis. Fairly common in forest-edge habitats in all areas visited.

LINCOLN'S SPARROW Melospiza lincolnii. Fairly common in lowland, partially-open, brushy habitats along the Grand Detour Portage, Little Buffalo River and Sass River.

SWAMP SPARRow Melospiza georgiana. Rather uncommon and local, occurring in wet, brushy habitats along the Grand Detour Portage, Little Buffalo River and Sass River.

Song Sparrow Melospiza melodia. Several singing males were observed 


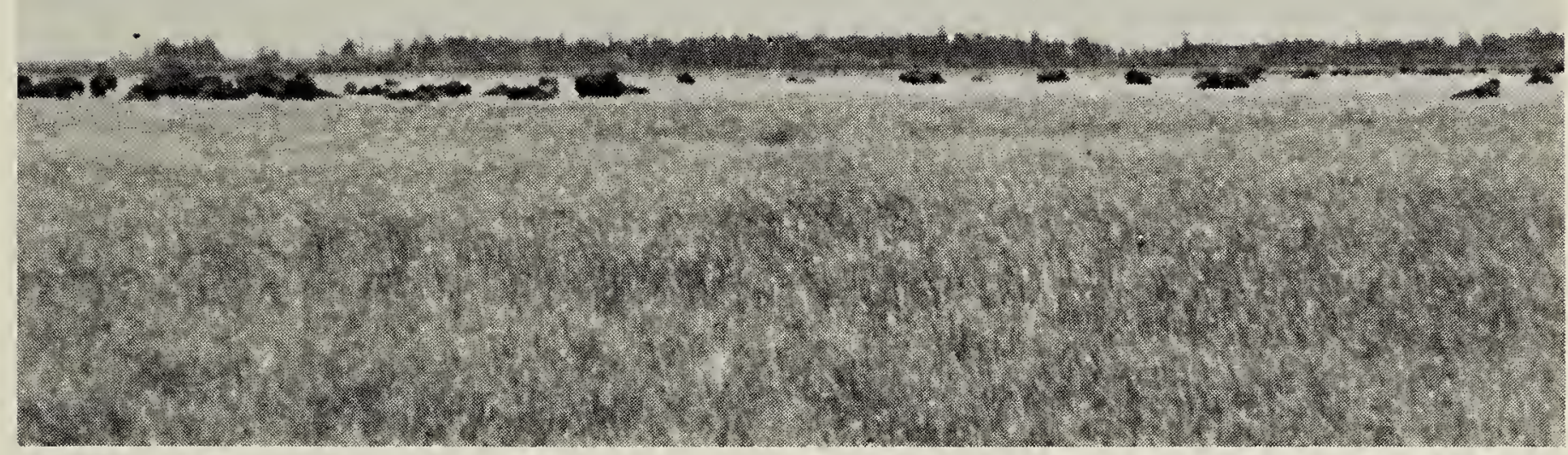

Photo by R. E. Stewart Herd of Bison at rest in large prairie near Little Buffalo River, June 18, 1955

in brushy habitats along the mouth of the Little Buffalo River and adjacent shore of Great Slave Lake during May 28-30. Not recorded elsewhere.

LAPland Longspur Calcarius lapponicus. Migrants were abundant in large flocks at Fort Smith during May 20-23.

\section{Notes on Other Vertebrates}

\section{MAMMALS}

BLACK BEAR Ursus americanus. Common along the lower course of the Sass River. Also fairly common in areas adjoining the Little Buffalo River. Several bears were seen and bear sign was frequently observed throughout the area.

Gray Wolf Canis lupus. Plentiful in the prairie sections located between the Slave and Little Buffalo Rivers. Numerous tracks were observed and howling heard at night. Tracks also were fairly common along the Little Buffalo River.

LyNX Lynx canadensis. Tracks were noted along the Sass River.

LEAST CHIPMUNK Eutamias minimus. Apparently uncommon. Only two (one collected) were seen, both near the Sass River.

RED SQUIRREL Tamiasciurus hudsonicus. Common in spruce forests in all areas visited.
BeAver Castor canadensis. Fairly common to abundant along the Little Buffalo and Sas's Rivers. Particularly numerous along the Little Buffalo River between the Sass and Nyarling Rivers.

Muskrat Ondatra zibetheca. Two were recorded on May 27 and one on May 28 along the Little Buffalo River.

SNowshoe HaRe Lepus americanus. Apparently very scarce. None was seen although droppings were observed at one location along the Sass River.

Moose Alces americana. Moose sign was frequently observed along the Little Buffalo and Sass Rivers.

Barren Ground Caribou Rangifer arcticus. One was observed at Tsu Lake on June 2. Tracks were seen along the mouth of the Little Buffalo River.

Bison Bison bison. Common in the prairie sections between the Little Buffalo and Slave Rivers. Many small groups and scattered individuals were seen and one large herd numbering about 300 individuals was observed. Bison sign was also frequently noted along the lower course of the Sass River.

\section{REPTILES}

RED-SIDED GARTER SNAKE Thamnophis sirtalis parietalis. One was col- 
lected along the Little Buffalo River, about one mile below the mouth of the Sass River on May 26 (specimen deposited in Canadian Wildlife Service collection at Fort Smith). Two others were seen on June 18 along a cattail slough near the Little Buffalo River, about four miles downstream from the mouth of the Sass River. These records may represent the northernmost of any reptile in North America.

\section{AMPHIBIANS}

Boreal Chorus Frog Pseudacris triseriata maculata. Choruses of this species were heard throughout the Grand Detour Portage area and along the Little Buffalo River during the period May 23-30.

Leopard Frog Rana pipiens. Robert P. Allen reported seeing Leopard Frogs near the mouth of the Sass River on May 26.

Wood Frog Rana sylvatica. Common in moist situations along the Little Buffalo and Sass Rivers. Freshly laid eggs were seen along the Great Slave Lake Shore (near mouth of Little Buffalo River) on May 29.

\section{Notes on Butterflies}

*RED-Disked AlPine Erebia discoidalis. Fairly common in prairies and sedge meadows along the Sass River (about two miles above its mouth during period June 5-10).

* FreiJa Fritillary Boloria freija. Fairly common in prairies and sedgemeadows along the Sass River during period May 26-June 10.

*Saga Fritillary Boloria frigga. Fairly common in prairies and sedge- meadows along the Sass River during period June 5-10.

Pearl Crescent Phyciodes tharos. One seen on prairie between Slave and Little Buffalo Rivers on June 18.

*Hoary Comma Polygonia gracilis. Common along Sass River during period June 5 - 17 .

* Mourning Cloak Nymphalis antiopa. Fairly common along Little Buffalo and Sass Rivers during period May 27 - June 17.

BANDED PURPLE Limenitis arthemis. One seen at Fort Smith on June 21.

* Silvery Blue Glaucopsyche lygdamus. Common along Sass River during period June 5-17.

* SPring AzUre Lycaenopsis argiolus. Common along Little Buffalo and Sass Rivers during period May 26 June 17.

*Tiger Swallowtail Papilio glaucus. Fairly common along the Sass River during period June 5-17.

*AUsonides Euchloe ausonides. One was collected on a small prairie on June 12.

*Mustard White Pieris napi. Common throughout the area from June $1-17$.

*Dreamy Dusky Wing Erynnis icelus. Fairly common near the brushy margins of prairies and sedgemeadows, along the Sass River during the period June $5-17$.

Note-A few butterflies of the genus Colias and one of the genus Speyeria were also observed, but not identified to species.

* Specimen collected.

\section{TWENTY-FOURTH ANNUAL SASKATCHEWAN CHRISTMAS BIRD COUNT, 1965}

One could almost use last year's summary again this year, since the 1965 Christmas Bird Count almost duplicates that of 1964. A total of 28 localities reported, 26 from Saskatchewan and one from each of Alberta and the Northwest Territories. Extremely cold weather prevailed during most of the count period. Of the 26 Saskatchewan counts, 18 were taken in sub-zero weather and seven of those at $-20^{\circ}$ or lower. Bangor reported the lowest Saskatchewan temperature with $-34^{\circ}$. This was exceeded only by Cambridge Bay, N.W.T., where Ramon Burron and Rowan 